verklaarde feiten ter zake waarvan de veroordeling al onherroepelijk is geworden. ${ }^{24}$ Met een dergelijke beslissing legt het hof immers niet zelf een sanctie op die het passend en geboden acht ter zake van het feit dat of de feiten die niet aan zijn oordeel onderworpen is/zijn, maar bepaalt het slechts welk gedeelte van de hoofdstraf en/of bijkomende straf(fen) en/of maatregel(en) geacht moet(en) worden door de eerste rechter te zijn opgelegd ter zake van het feit dat of de feiten die niet aan het oordeel van het hof is/zijn onderworpen. ${ }^{25}$ In een vernietiging 'wat betreft de strafoplegging' zijn dan ook niet begrepen beslissingen als bedoeld in artikel 423 lid $4 \mathrm{~Sv}$. Indien de Hoge Raad een bestreden uitspraak 'wat betreft de strafoplegging' vernietigt, bliift de beslissing in die uitspraak met betrekking tot het bepalen van de straf dus in stand. Dat is anders indien de bestreden uitspraak van het hof algeheel wordt vernietigd. In dat geval omvat de vernietiging van die uitspraak ook de in artikel 423 lid 4 Sv bedoelde beslissing. De Hoge Raad acht het oordeel van het hof dat het in zijn arrest van 7 april 2017 niet meer had te oordelen over de sanctieoplegging voor de feiten 3, 4 en 5, omdat bij arrest van het hof van 19 november 2014 de straf voor die feiten al was bepaald en die strafbepaling na terugwijzing door de Hoge Raad niet meer aan de orde was, dan ook juist. Hij voegt daar echter nog wel het volgende aan toe:

'In de vernietiging "wat betreft de strafoplegging" zijn in beginsel niet begrepen de beslissingen als bedoeld in art. $361 \mathrm{~Sv}$ omtrent een vordering van de benadeelde partij, nu die beslissingen worden bepaald door de civielrechtelijke rechtsverhouding tussen de verdachte en de benadeelde partij.

Van de beslissing omtrent een vordering van de benadeelde partij moet worden onderscheiden de beslissing ter zake van het opleggen van een schadevergoedingsmaatregel als bedoeld in art. 36f Sr. De oplegging van de schadevergoedingsmaatregel is wel begrepen in de vernietiging "wat betreft de strafoplegging", tenzij anders wordt vermeld in de uitspraak van de Hoge Raad.

Aanleiding voor zo'n andersluidende beslissing van de Hoge Raad kan bijvoorbeeld bestaan in het geval dat in de bestreden uitspraak meerdere feiten zijn bewezenverklaard en ten aanzien van verschillende van die feiten een vordering van een benadeelde partij is toegewezen, terwijl de vernietiging door de Hoge Raad wordt beperkt tot één van die feiten. De vernietiging van de beslissingen met betrekking tot dat feit omvat dan de toewijzing van de vordering van de benadeelde partij die betrekking heeft op dat feit, maar niet de toewijzing van de vordering(en) met betrekking tot de overige bewezenverklaarde feiten. Dat kan anleiding vormen om de schadevergoedingsmaatregel(en) die is (of zijn) opgelegd met betrekking tot de schade die is veroorzaakt door de feiten waarvan de bewezenverklaring in stand blijft,

24. Vgl. ook met betrekking tot art. 359 lid 5 en 6 Sv HR 9 mei 2000 ECLI:NL:HR:2000:AA5734.

25. Vgl. HR 2 februari 2010, ECLI:NL:HR:2010:BK3202. buiten de vernietiging van de strafoplegging te houden. Een voorbeeld daarvan betreft HR 27 januari 2015, ECLI:NL:HR:2015:132.

Voorts kan worden gewezen op het geval waarin de grond voor cassatie uitsluitend is gelegen in de (gehele of gedeeltelijke) toewijzing van de vordering van de benadeelde partij, terwijl in verband met die toewijzing tevens een schadevergoedingsmaatregel voor hetzelfde bedrag is opgelegd. In dat geval wordt in beginsel de bestreden uitspraak uitsluitend vernietigd met betrekking tot de beslissing op die vordering en de oplegging van de schadevergoedingsmaatregel en niet met betrekking tot de strafoplegging als geheel.'

\section{NTS 2020/38}

HR 4 februari 2020, 19/03651, ECLI:NL:HR:

2020:185

OM-cassatie. Beklag, beslag ex art. 94 Sv op gegevensdragers onder kla(a)g(st)er(s) i.v.m. onderzoek naar OMG Caloh Wagoh, art. $552 a$ Sv

\section{Aantekening redactie}

In verband met het onderzoek naar motorbende Caloh Wagoh is (o.m.) onder klager op grond van artikel $94 \mathrm{~Sv}$ een groot aantal gegevensdragers in beslag genomen (telefoons, navigatie, gps-tracker, iPad etc.). Het openbaar ministerie verzette zich in de 552a-procedure voor de rechtbank tegen teruggave nu er nog onderzoeksbelang anwezig was. Bij inbeslagneming op basis van artikel 94 Sv staan centraal de waarheidsvinding, ook wat betreft het aantonen van wederrechtelijk verkregen voordeel als bedoeld in artikel 36e $\mathrm{Sr}$, en het verwijderen uit het maatschappelijke verkeer van voorwerpen waarvan de verbeurdverklaring of onttrekking aan het verkeer kan worden bevolen. In geval van een beklag van de beslagene tegen een op de voet van artikel $94 \mathrm{~Sv}$ gelegd beslag dient de rechter te beoordelen of het belang van strafvordering het voortduren van het beslag vordert. Het belang van strafvordering verzet zich tegen teruggave indien het veiligstellen van de belangen waarvoor artikel $94 \mathrm{~Sv}$ de inbeslagneming toelaat, het voortduren van het beslag nodig maakt. Dat is bijvoorbeeld het geval wanneer de desbetreffende voorwerpen kunnen dienen om de waarheid aan de dag te brengen ook in een zaak betreffende een ander dan de klager - of om wederrechtelijk verkregen voordeel aan te tonen. Voorts verzet het door artikel $94 \mathrm{~Sv}$ beschermde belang 
van strafvordering zich tegen teruggave indien niet hoogst onwaarschijnlijk is dat de strafrechter, later oordelend, de verbeurdverklaring of onttrekking aan het verkeer van het voorwerp zal bevelen, al dan niet naar aanleiding van een afzonderlijke vordering daartoe als bedoeld in artikel $36 \mathrm{~b}$ lid 1 onder $4^{\circ} \mathrm{Sr}$ in verbinding met artikel $552 \mathrm{f} \mathrm{Sv}{ }^{26}$ De rechtbank heeft in de onderhavige zaak bij beschikking van 28 mei 2019 het beklag op grond van artikel 552a Sv tegen de inbeslagneming van dertien gegevensdragers (waaronder een gps-tracker) onder de klager gegrond verklaard per 28 juni 2019, indien daarover op die datum door het openbaar ministerie nog geen beslissing tot teruggave is genomen. Het onderzoek duurde de rechtbank kennelijk te lang, waardoor het openbaar ministerie als het ware nog een maand aan 'onderzoeksbelang' gegund kreeg:

'Hetgeen van de zijde van het openbaar ministerie is aangevoerd rechtvaardigt naar het oordeel van de rechtbank niet veel langer de conclusie dat het belang van strafvordering zich in dit geval verzet tegen de beëindiging van het beslag. Hoewel een groot aantal gegevensdragers in beslag is genomen en het begrijpelijkerwijs veel tijd kost om alles te doorzoeken is de rechtbank van oordeel dat het belang van klager bij teruggave van de gegevensdragers thans, na een halfjaar, zwaarder moet wegen. De rechtbank stelt een termijn van één maand waarbinnen het onderzoek dient te worden afgerond. De rechtbank zal het klaagschrift dan ook per 28 juni 2019 gegrond verklaren ten aanzien van de gegevensdragers waarover op 28 juni 2019 door het OM nog geen beslissing is genomen en de teruggave daarvan gelasten.'

Het middel van het openbaar ministerie klaagde onder meer dat het oordeel van de rechtbank dat het belang van de klager bij teruggave van dertien in de beschikking van de rechtbank vermelde gegevensdragers 'thans, na een half jaar', zwaarder moet wegen dan het belang van strafvordering, zonder nadere motivering, die ontbreekt, niet begrijpelijk is. Het openbaar ministerie had hiermee een punt. De rechtbank erkent namelijk dat er nog een onderzoeksbelang aanwezig is. Dan kan een klaagschrift enkel gegrond worden verklaard wanneer voortduren van het beslag in strijd zou zijn met de proportionaliteit en subsidiariteit. De omstandigheden van het geval kunnen immers meebrengen dat de rechter bij de beoordeling van een beklag over inbeslagneming ter motivering van zijn beslissing ervan blijk dient te geven te hebben onderzocht of er een redelijke verhouding bestaat tussen het belang van de strafvordering enerzijds en de belangen van de klagers anderzijds. Verklaart de rechtbank het beklag gegrond omdat voortduring van het beslag in strijd zou zijn met de eisen van proportionaliteit, dan dient de rechtbank haar oordeel wel toereikend te motiveren. Het gaat dan - anders gezegd - om uitzonderlijke gevallen die goed moeten worden gemoti- veerd. Dat is hier niet gebeurd. De rechtbank gaf geen inzicht waarom - anders dan het openbaar ministerie kennelijk meende - het onderzoek naar haar oordeel binnen een maand (wel) afgerond zou kunnen zijn en waarom geen genoegen kan worden genomen met de stelling van de officier van justitie dat het beslag wordt opgeheven zodra het onderzoek daaraan is afgerond. Ook had de rechtbank niet voldoende kenbaar gemaakt in welk belang de klager precies wordt getroffen en waarom het beslag na een halfjaar zo onevenredig zwaar drukt op de klager dat dit (niet nader omschreven) belang zwaarder moet wegen dan het belang van strafvordering. Daar komt nog bij dat de wet niet voorziet in een voorwaardelijke last tot teruggave. De Hoge Raad oordeelde dat een concrete en nauwkeurige belangenafweging toegespitst op de klager ontbrak in de beschikking van de rechtbank en achtte het middel gegrond. Met betrekking tot die voorwaardelijke last tot teruggave overweegt de Hoge Raad nog het volgende:

'Naar aanleiding van de gegrondverklaring door de rechtbank van het beklag ten aanzien van de hierboven genoemde goederen "per 28 juni 2019" en het gelasten van de teruggave daarvan aan de klager "indien daarover op 28 juni 2019 door het OM nog geen beslissing is genomen" merkt de Hoge Raad nog het volgende op. De wet voorziet niet in de mogelijkheid van een voorwaardelijke beslissing over strafvorderlijk inbeslaggenomen voorwerpen. Is de rechter van oordeel dat het belang van strafvordering zich (nog) verzet tegen de teruggave van de inbeslaggenomen voorwerpen, dan dient hij het klaagschrift waarin de teruggave van die voorwerpen wordt verzocht ongegrond te verklaren. Is daarvan geen sprake, dan dient in de regel teruggave te worden gelast (vgl. HR 12 november 2019, ECLI:NL:HR:2019:1692).'

\section{NTS 2020/39}

\section{HR 4 februari 2020, 18/05488, ECLI:NL:HR:} 2020:190

\footnotetext{
Aanhoudingsverzoek niet gemachtigde raadsman voorafgaand aan tz. per e-mail gedaan op de grond dat hij verdachte niet kan bereiken door Hof afgemezen o.g.v. overmeging dat formeel gezien geen sprake is van aanhoudingsverzoek. Heeft Hof verzuimd uitdrukkelijk en gemotiveerd te beslissen op aanhoudingsverzoek?
} 